\begin{tabular}{|c|c|c|}
\hline 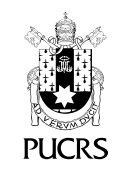 & $\begin{array}{l}\text { ESCOLA DE } \\
\text { HUMANIDADES }\end{array}$ & $\begin{array}{l}\text { Revista Digital do Programa de Pós-Graduação em Letras da PUCRS } \\
\text { Letrônica, Porto Alegre, v. 13, n. 1, p. 1-10, jan.-mar. } 2020 \\
\text { e-ISSN: } 1984-4301\end{array}$ \\
\hline de) $\mathrm{http}: / / \mathrm{dx}$ & $\mathrm{rg} / 10.15448 / 1984-4301.2020 .1 .34925$ & \\
\hline
\end{tabular}

\title{
Uma escutadeira que conta: a memória como construtora de identidade e potencializadora da escrita em Meus Desacontecimentos, de Eliane Brum
}

\author{
A Scout that counts: the memory as a builder of identity and potentiator of writing in \\ "Meus desacontecimentos", by Eliane Brum \\ Una escuchadora que cuenta: la memoria como constructora de la identidad y \\ potenciadora de la escritura en "Meus desacontecimentos"de Eliane Brum
}

\section{Karine Conte de Mattos da Costa ${ }^{1}$}

orcid.org/0000-0001-5073-2603

karine.costa@edu.pucrs.br

Recebido em: 18 jul. 2019. Aprovado em: 21 nov. 2019 Publicado em: 7 abr. 2020.

\author{
(c) (i) \\ Artigo está licenciado sob forma de uma licença \\ Creative Commons Atribuição 4.0 Internacional.
}

Resumo: O presente artigo tem por objetivo analisar como a autoficção na obra Meus Desacontecimentos, de Eliane Brum, torna-se fundamental na formação e afirmação da identidade da autora como, antes de tudo, escritora. Desta forma, analisa-se o papel tendencioso, precursor e libertário da escrita nas memórias da narradora e a importância disso para lidar com a própria história e superar medos e traumas. Para compreender o papel da recordação dentro do processo identitário, recorre-se aos conceitos já abordados por Paul Ricoeur (2007), Aleida Assmann (2011), Laura Reestrepo (2008), dentre outros. Sendo assim, entende-se que, na obra em análise, a infância é recriada tal qual um palco onde a vida é encenada e seleciona o elenco de influência que deseja reforçar, bem como salienta o protagonismo dado ao ato da escrita dentro do passado e do presente. Palavras-chave: Memória. Identidade. Autoficção. Autobiografia.

Abstract: The objective of this article is to analyze how the autofiction in Eliane Brum's Meus Desacontecimentos becomes fundamental in the formation and affirmation of the author's identity as, first of all, a writer. In this way, we analyze the tendentious, precursory and libertarian role of writing in the narrator's memories and the importance of this to deal with our own history and overcome fears and traumas. In order to understand the role of recall within the identity process, we use the concepts already discussed by Paul Ricoeur (2007), Aleida Assmann (2011), Laura Reestrepo (2008), and others. Thus, it is understood that in the work under analysis, childhood is recreated just like a stage where life is staged and selects the cast of influence that wishes to reinforce, as well as stresses the leading role given to the act of writing in the past and gift.

Keywords: Memory. Identity. Autofiction. Autobiography.

Resumen: Este artículo tiene como objetivo analizar como la autoficción en la obra Meus Desacontecimentos, de Eliane Brum, se vuelve fundamental en la formación y en la afirmación de la identidad de la autora como, antes que nada, escritora. Así, se analiza el papel tendencioso, precursor y libertador de la escritura en las memorias de la narradora y la importancia de ello, para hacer frente a la propia historia y superar los miedos y traumas. Para comprender el papel de la recordación en el proceso identitario, se utilizan los conceptos que abordan Paul Ricoeur (2007), Aleida Assmann (2011), Laura Restrepo (2008), entre otros. Por lo tanto, se entiende que, en la obra investigada, se recrea la infancia como si fuera un escenario, donde se escenifica la vida, al seleccionar el elenco de influencia que desea reforzar, así como señala el protagonismo que da al acto de la escritura, en el pasado y en el presente.

Palabras clave: Memoria. Identidad. Autoficción. Autobiografía.

Pontifícia Universidade Católica do Rio Grande do Sul, Programa de Pós-Graduação em Letras, Escola de Humanidades, Porto Alegre, RS, Brasil. 


\section{Introdução}

"Sou muito mais 'olhadeira' e 'escutadeira', que 'faladeira', 'perguntadeira'. Eu sempre olho muito e fico escutando, tentando ver o que está acontecendo". (Eliane Brum)

"Uma escutadeira que conta" (BRUM, 2017, p. 29), assim se define Eliane Brum. Conhecida principalmente pela carreira jornalística, nasceu em ljuí, RS, no ano de 1966, e formou-se em jornalismo pela PUCRS em 1988. Sua experiência em lugares como o Jornal Zero Hora, no qual trabalhou por 11 anos, e a Revista Época (lá atuou por 10 anos), deram espaço e segurança para amadurecer e explorar a sua escrita. Porém, mais do que prática, a vida jornalistica the deu voz para falar por muitos, inclusive pelos silêncios que trazia em si mesma. A ênfase de sua escrita sempre esteve ligada às identidades anônimas e às vivências do cotidiano, bem como às histórias de pessoas comuns, da periferia.

Atualmente, Eliane escreve em uma coluna do jornal El País e no jornal britânico The Guardian, todavia, sua produção não se detém mais apenas nos jornais, pois já abarca livros, documentários, crônicas e ensaios, muitos deles premiados. Os limites entre a linguagem literária e a jornalistica são contestados por ela, porque, ao narrar os acontecimentos (ou desacontecimentos, conforme veremos na sequência), sua linguagem transita entre a prosa poética, a ficção e o relato, diferenciando-se do fazer midiático ao qual estamos acostumados.

Sendo assim, há uma mistura do gênero jornalístico com a história e a memória, o que ela chama de "desacontecimento" ao falar que "A carne da minha reportagem são os 'desacontecimentos', palavra que dá conta de uma escolha: escrevo sobre a extraordinária vida comum, sobre o cotidiano dos homens e das mulheres que tecem os dias e também o pais, mas nem sempre são cruciais" (BRUM, 2013 apud VENTURA; ABIB, 2013, p. 13). Devido a todos os traços marcantes de seu trabalho, Eliane é conhecida pelo chamado "jornalismo dos desacontecimentos", no qual o foco está na narração da história do outro, sem que precise de algo extraordinário além da própria vida:

\begin{abstract}
Sob esta perspectiva, acredita-se que o Jornalismo de Desacontecimentos, ao interligar sensibilidade, dialogia e afetos em sua prática, amplia a possibilidade da experiência de compreensão do outro em sua totalidade. seja no nivel da relação entre jornalista e fonte, como entre o leitor e o personagem narrado. Isso porque esses dois niveis coexistem em um plano de interdependência: é somente ao estabelecer uma relação de reciprocidade entre repórter e fonte que se pode gerar no leitor a compreensão humana (MORIN, 2000) acerca da presença do outro em si-mesmo, tal qual manifesta Brum em seu fazer noticioso: "não existiria esse eu sem todos esses outros" (BRUM, 2014 apud VENTURA; ABIB, 2016, p. 58).
\end{abstract}

O estilo diferenciado dentro do jornalismo fez com que as obras da autora logo se destacassem e gerassem livros que reúnem as suas reportagens especiais. Coluna Prestes: 0 avesso da lenda (Artes e Oficios, 1994) é a obra que dá a Brum o prêmio Açorianos de autorarevelação e fala do percurso do chamado "povo do caminho" (nem rebeldes e nem governistas" em plena era da República Velha². Logo em seguida, $A$ vida que ninguém vê (Arquipélago Editorial, 2006) instaura de vez a temática do desacontecimento por meio de histórias comuns, resultando em um documentário e um livro ganhador do prêmio Jabuti de 2007, categoria melhor livro de reportagem. Sobre essa obra, a sinopse remete o leitor a um olhar pelos olhos do outro, um mergulho na vivência alheia e, por meio disso, uma reflexão sobre sua própria história, funções que fazem do produto final algo não só jornalístico, mas também literário:
Uma repórter em busca dos acontecimentos que não viram notícia e das pessoas que não são celebridades. Uma cronista à procura do extraordinário contido em cada vida anôni- ma. Uma escritora que mergulha no cotidiano para provar que não existem vidas comuns. $O$ mendigo que jamais pediu coisa alguma. $O$ carregador de malas do aeroporto que nunca voou. O macaco que ao fugir da jaula foi ao bar beber uma cerveja. O álbum de fotografias atirado no lixo que começa com uma moça de familia e termina com uma corista. O homem 
que comia vidro, mas só se machucava com a invisibilidade. Essas fascinantes histórias da vida real fizeram sucesso no final dos anos 90, quando as crônicas-reportagens eram publicadas na edição de sábado do jornal Zero Hora. Reunidas agora em livro, formam uma obra que emociona pela sensibilidade da prosa de Eliane Brum e pela agudeza do olhar que a repórter imprime aos seus personagens - todos eles tão extraordinariamente reais que parecem saidos de um livro de ficção. ${ }^{3}$

Ao afirmar que as personagens parecem "saídos de um livro de ficção", lembramos que as histórias (orais ou escritas) são fundamentais dentro do desenvolvimento de uma identidade e de uma história individual ou coletiva (HALL, 2005). Dessa forma, Brum compõe um mosaico de identidades por meio de sua obra, o que corrobora para uma memória de representação coletiva transmitida por meio da mídia e da literatura. Se o objeto de estudo da literatura é, segundo Sousa (2007, p. 52) "constituído pela literariedade, isto é, o modo especial de elaboração da linguagem inerente às composições literárias, caracterizado por um desvio em relação às ocorrências comuns da linguagem", torna-se relevante afirmar que Eliane Brum, ainda que no campo jornalístico, faz literatura ao valer-se da plurissignificação da linguagem.

Outra de suas obras, O olho da rua - uma repórter em busca da literatura da vida real, traz a história de parteiras da Amazônia e termina com a experiência que resultará, dentre outras, num processo de busca da própria autora: ela acompanhará os 115 últimos dias de uma paciente com câncer terminal, o que a fará repensar os significados da morte e da escrita e trará inspiração para sua estreia no gênero romance com Uma duas, abordando a temática do relacionamento de uma mãe e sua filha.

Seguindo a cronologia de sua atuação, a autora lança em 2013 A menina quebrada, ganhadora do prêmio Açorianos de melhor livro do ano. Por fim, chegamos na obra cuja análise pretende-se aprofundar, Meus desacontecimentos: a história da minha vida com as palavras, publicada em $2014 \mathrm{e}$ que traz para o foco da narrativa a própria infância da narradora. A retrospectiva parcial da obra de
Eliane Brum (que possui também documentários, ensaios, artigos e outras produções) não foi feita em vão, mas sim para nos alertar do que agora já parece óbvio: seu gosto por contar histórias e sua habilidade para tal feito. Logo, é necessário lembrar que a autoficção permite recriar sentidos para a memória e Brum sabe exatamente como fazer isto. Entretanto, ao "despir-se" em uma obra, como ela mesma diz, o efeito torna-se igual?

\begin{abstract}
Como contadora de histórias reais, a pergunta que me move é como cada um inventa uma vida. Como cada um cria sentido para os dias, quase nu e com tão pouco. Como cada um se arranca do silêncio para virar narrativa. Como cada um habita-se (BRUM, 2017, p. 7).
\end{abstract}

\section{A memória dos desacontecimentos}

"Esta é a minha memória. Dela eu sou aquela que nasce, mas também sou a parteira". (Eliane Brum)

Ao abrir Meus desacontecimentos, o primeiro título oferecido já aponta a temática da obra e também a sua maior controvérsia: "Nossa vida é nossa primeira ficção" (BRUM, 2017, p. 7). "Nossa vida", ou seja, a da narradora e também a do leitor, remete a fatos reais e conhecidos da história que possuimos, tanto individualmente quanto coletivamente. Essa história é imutável, pois não podemos recriar o passado, por mais feliz ou triste que tenha sido. Entretanto, ao afirmar que essa vida é nossa primeira forma de ficcionalizar a realidade, evocamos não mais a biografia pura, mas sim a memória e seu poder de construir sentidos e de escolher dentre eles quais desejamos recordar e quais preferimos ocultar.

Aleida Assman, na obra Espaços da recordação (2011), chama atenção para o processo seletivo da memória. Ela classifica dois processos nos quais ela atua: VIS E ARS. Na memória ARS temos o uso da mnemotécnica, da arte da memória instrumental, como por exemplo a função de decorar e recuperar informações especificas. Já na memória VIS temos a potência da recordação 
como formadora de identidade, pois é expressa a possibilidade de despertar uma memória por meio de um processo que começa do presente e se desloca, como uma força imanente e com leis próprias. Nesse aspecto, esquecimento e recordação estão intricados, pois um é possibilitador do outro. Além disso, temos o nascimento da filologia como arte disciplinada da recordação. Tais ideias nos ajudam a entender a memória como chave da representação do sujeito e de sua forma de "autonarrar":

$\mathrm{O}$ ato do armazenamento acontece contra o tempo e o esquecimento, cujos efeitos são superados com a ajuda de certas técnicas. $O$ ato da recordação, por sua vez, acontece dentro do tempo, que participa ativamente do processo. No que diz respeito à psicomotricidade da recordação, esquecimento e recordação estão indissocialmente intricados. Um é possibilitador do outro. Podemos também dizer: o esquecimento é o oponente do armazenamento, mas cúmplice da recordação (ASSMAN, 2011, p. 34).

Sendo assim, a narradora de Meus desacontecimentos já revela que, antes de tudo, se insere em um processo no qual encontrará a potência VIS e não apenas usará do processo laborioso, como também imaginativo. Além disso, a afirmação inicial do livro concorda com o que Paul Ricoeur nos diz ao refletir sobre memória e imaginação e com o que a própria Eliane Brum teoriza sobre a memória:

É sob o signo da associação de ideias que está situada essa espécie de curto-circuito entre memória e imaginação: se essas duas afecções estão ligadas por contiguidade, evocar uma portanto, imaginar - é evocar outra, portanto, lembrar-se dela. Assim, a memória, reduzida à rememoração, opera na esteira da imaginação (RICOEUR, 2007, p. 25).

Há uma autonomia na forma como damos carne ao nosso nome com a vida que construímos - e não com a que herdamos. E há história que veio antes, barro para criar uma existência que se sabe menos autônoma do que a modernidade promete. Podemos desconhecê-la, mas de algum modo ela ainda estará lá. Eu escolho a memória. A desmemoria assombra porque não a nomeamos, respira em nossos porões como monstros sem palavras. A memória, não. É uma escolha do que esquecer e do que lembrar - e uma oportunidade de ressignificar o passado para ganhar um futuro. Pela memória nós colocamos não só em movimento, mas nos tornamos o próprio movimento. Gesto humano, para sempre incompleto (BRUM, 2017, p. 74).

O "gesto incompleto" da memória induz para que a narradora se volte para o maior espelho da sua origem: a infância. Ainda que o faça com um objetivo claro, que é mostrar a história da vida com as palavras, ou seja, enfatizar o projeto de nascimento da "Eliane escritora" por meio do poder de construção de um "corpo de letras", é necessário revisitar a infância e seus fantasmas para que haja ressignificação, o que acontece não pelo mnesis de simplesmente lembrar, mas sim pelo processo de anamnesis descrito por Ricoeur, no qual "a distinção entre MNSE e ANAMNSESIS apoia-se em duas caracteristicas: de um lado, a simples lembrança sobrevém a maneira de uma afecção, enquanto a recordação consiste numa busca ativa." (RICOEUR, 2007, p. 37). Desse modo, a MNSE trata da recordação instantânea, a evocação simples, o grau zero da recordação, enquanto a ANAMNESE fala do esforço da recordação, do processo laborioso de reconstrução. Para Eliane Brum e seus desacontecimentos, é essa possibilidade de reconstrução que importa na narrativa.

Sobre a decisão de construir um relato de memórias, a autora conta que a ideia partiu de sua viagem com a instituição Médico sem fronteiras para a Bolivia ${ }^{4}$, a fim de escrever sobre a situação das pessoas que convivem com a doença de Chagas. Lá, conhece uma menina chamada Sônia, cujos olhos seriam "de velha" por ter de lidar diariamente com a morte. A menina the faz um apelo antes que ela parta: não me deixe morrer. Diante disso, Eliane diz ter entrado em conflito por entender que apenas contar a história de Sônia não era o suficiente para salvá-la. As palavras, diante de tanta tristeza e desamparo carregados desde a tarefa de acompanhar doentes terminais até a presente experiência na Bolívia, geram não apenas uma circularidade ao redor da temática da morte como também paralisam a inspiração da autora

4 STRICHTER, Luzimar. Eliane Brum no divã: meus desacontecimentos. 2018. Disponivel em: https://www.youtube.com/watch?V=Sgm38Aj3MsU\&t=2156s. Acesso em: 28 maio 2019. 
durante duas semanas. Para sair de seu limbo, ela resolve que precisa nortear a memória para o momento no qual mais precisou ser salva e dos quais foram elas que trouxeram redenção: a infância. Era preciso reencontrar a criança que a morte também perseguia e, assim, tornar a lembrança a potencializadora da recriação de uma história:

Isso significa que a faculdade da lembrança se revela insuficiente para a autoficção e que não se trata mais simplesmente de procurar essa lembrança atrás de si, no antetexto, mas também diante de si, no texto e na própria escrita, tanto na retrospecção quanto na prospecção que acompanha a busca inventiva da escrita, pois a lembrança é aqui fonte autoestimulante de recriação: ao rememorar aquele episódio, o eu repete sua primeira vez [...] Igualmente, ao ser rememorado, o referencial se reelabora constantemente, se reproduz e se dá a ler em sua unidade própria como variação dele mesmo (VILAIN, p. 168, 2014).

Tal fato explica porque o livro é dedicado à irmã, que ela nem mesmo conheceu. "Lembro que, quando tudo começou, era escuro" (BRUM, 2017. p. 9). Tal qual o Gênesis da terra, cujo principio era o verbo, a narradora fala de sua pré-história percebendo que o seu escuro era fruto de uma ausência de palavras. Porém, o "eu caos" (BRUM, 2017, p. 9), explode para narrar a dor ao afirmar que "Desde o início o mundo doeu em mim. Dentro, mas também fora. Alguns creem que as memórias da primeira infância ou são boas ou não existem (BRUM, 2017, p. 9). De forma direta, o livro relata que essa infância não foi doce, mas repleta de luto, peso e respiro por meio da palavra. "A morte é o mundo sem palavras. E é curioso que minha primeira lembrança seja a morte. Como se eu tivesse nascido morta. E a vida só tivesse acontecido alguns anos depois, quando eu já era um zumbi crescido" (BRUM, 2017, p. 9). Ao afirmar que nasceu de vários túmulos, conhecemos a história da irmã da narradora, cuja morte precoce aos cinco meses deixou a familia devastada:

Durante a infância minha mãe nos carregou, a mim e a meus irmãos, para o túmulo da filha que morreu. Minha irmã, a Maninha. E esse "carregou" tem mais sentidos do que o literal. Talvez minha mãe não pudesse acreditar e precisasse repetir, repetir, repetir. E a cada repetição, eu, a filha viva, sentia que a viva era a outra. E, mais morta do que viva, eu falhava em fazer renascer as partes ausentes da minha mãe. Só muito mais tarde eu descobriria que esta é a sina dos filhos que sobrevivem, chapinhando no lago escuro e sem fundo que é a dor sem consolo dos pais órfãos. Diante daquele túmulo, eu me esforçava para chorar, eu tentava sofrer pela outra, mas não conseguia. Poderia ser uma cena de cinema. A menina pequena de vestido rodado, com uma Chiquinha na cabeça, diante do túmulo de onde um anjo com asas a olhava. Mas, se alguém espiasse os meus pensamentos, saberia que sentia um alívio culpado pela morte da outra. Intuia que, se ela não tivesse morrido, eu não teria nascido. E mesmo torta, mesmo sendo um anjo de pernas tortas, eu queria viver. Mas não sabia como. Não ainda (BRUM, 2017, p. 12-13).

Laura Restrepo ([2008]), ao refletir sobre a infância nas narrativas de autoficção, alerta que a criança "Trata-se de uma personagem pequena e fantasmagórica e, no entanto, cheia de poderes. Encapsulada em cada um de nós, parece guardar o segredo de nossa origem e, portanto, a chave do nosso destino". Além disso, ela seria para o adulto como a caixa preta do avião, pois guarda as informações essenciais sobre quem somos e o que desejávamos ser.

Por isso, partir da criança que fomos para compreensão do presente por meio da memória "é muito mais a história de como vamos deixando ela para trás; do tempo que passa, do que se leva; do fim, que já se percebe desde o outro extremo" (RESTREPO, [2008]). Se a grande questão da memória está não apenas no que as lembranças guardam, mas também em como relembramos ou não, reafirma-se a ideia da imaginação como grande aliada da reinvenção da infância.

Eliane Brum, ao propor o mergulho na própria história, tendenciosamente conduz o leitor a ver a potencialidade de sua escrita como salvadora de angústias. O "corpo de letras", nu para leitura, traz sua grafia em uma menina que, para sobreviver à morte constante que a rodeava, escreve. Logo, vários fragmentos da obra interrompem a diacronia para apenas falar sobre o poder libertador da escrita e o quanto a vida da narradora é marcada pelo refúgio que encontrou na escrita sob o ponto de vista da narradora adulta que retrospecta os conflitos e que os supera por meio da palavra: 
Vivo tudo no corpo. Às vezes me perguntam o que aconteceria comigo se não existisse a palavra escrita. Eu respondo: teria me assassinado, consciente ou não de que estava me matando. É uma resposta dramática, e eu sou dramática. O que tento dizer é que, se não pudesse rasgar o papel com a caneta, ainda que numa tela digital, eu possivelmente rasgaria o meu corpo. E, em algum momento, o rasgaria demais (BRUM, 2017, p. 16).

Dizem que apanhei apenas uma vez do meu pai. Tinha três ou quatro anos. Ele atravessara a noite escrevendo um discurso. Na manhã seguinte, eu peguei uma tesoura e esquartejei o papel, as palavras, as letras, em pedaços tão pequenos que não puderam ser colados. Nem lidos. Dizem que meus gritos foram ouvidos de longe. Eu não me lembro.

Talvez tenha sido o momento em que me tornei escritora (BRUM, 2017, p. 53).

Hoje, ao lançar meus anzóis no lago nebuloso do passado, em busca de um mapa cujo único destino sou eu, percebo que escrever me salvou de tantas maneiras e também desta. Desde pequena tenho muita raiva - e quase nenhuma resignação. A reportagem me deu a chance de causar incêndios sem fogo e espernear contra as injustiças do mundo sem ir para a cadeia. Escrevo para não morrer, mas escrevo também para não matar (BRUM, 2017, p. 61).

Pela palavra escrita eu tornava-me capaz de transcender o concreto, transformar impotência em potência. Fui salva pela palavra escrita, quando comecei a ler - (e talvez) em definitivo quando escrevi. E - importante - quando fui lida (BRUM, 2017, p. 97).

Ao construir a metáfora do salvamento, a narradora cria para si o reflexo ideal da adulta jornalista e escritora. Mostrar sua ligação com as histórias, não apenas justifica seu estado atual como também revela uma espécie de oráculo cumprido. Sobre isso, destaca-se a ideia de que "da mesma forma que Sherazade conta as suas histórias para afastara ameaça de morte que paira sobre ela, o narrador do eu também escreveria para evitar a morte" (CARLOS; ESTEVES, 2009, p. 16). Não é à toa que a metáfora de Sherazade é usada também por Eliane ao dizer que "Eliane Cristina nunca tinha ouvido falar das mil e uma noites. Mas talvez as meninas já nasçam com uma Sherazade sussurrando nos ouvidos" (BRUM, 2017. p. 28), pois, por meio da reconstrução, melhora-se a autoimagem e reflete-se sobre influências, além de envolver o outro na história contada, fato que coloca ainda mais a narrativa biográfica sob o viés da suspeita.

\section{Considerações finais}

"Há realidades que só a ficção suporta. Precisam ser inventadas para contadas".

(Eliane Brum)

"Ao redor da criança evocada, aparecem os atores de elenco" (RESTREPO, [2008]). Tal afirmação conduz ao fato de que, ao desenhar a vida como uma grande encenação, os membros da familia funcionam como os demais atores envolvidos na representação literária. Sendo assim, as relações familiares tornam-se parte da mensagem que a narradora de Meus desacontecimentos deseja dar ao leitor.

Fato é que, por mais que a proposta seja escrever uma biografia, a grande protagonista da história nem mesmo é humana, mas sim encarnada e desejada: a palavra. É a palavra escrita o objeto central da vida da personagem e, por isso mesmo, o foco central de todas as histórias. Tudo caminha para dizer ao leitor que ela estava ali, desde o principio, salvando a narradora. Por isso, as demais personagens acabam compactuando com o cerco da escrita ao redor da narradora.

A primeira personagem cujas ações já apontam para o futuro jornalista é a empregada. A menina a observa chorando, absorta ao ouvir uma novela no rádio. "Pressenti ali o que só racionalizaria muitos anos depois: o poder da história contada" (BRUM, 2017, p. 23). Seria a origem da observação dos desacontecimentos? Perceber que a ficção pode emocionar faz a narradora se sentir aquecida e fascinada por observar que, mesmo quando as empregadas mudam, o hábito das novelas permanece e ouvir histórias traz comoção:

A novela de rádio rompeu a escuridão da ca-
sa-túmulo como um daqueles raios de sol que
se enfiam por um buraco da parede e fazem
nascer flores em ruinas de guerra. As palavras
rastejaram para dentro das minhas orelhas
com suas unhas compridas, raramente limpas,
e me contaminaram para sempre. Foi ali que
comecei a me tornar uma escutadeira que
conta. E conta. Para contar (BRUM, 2017, p. 29).

O jogo da possibilidade de ter tido o nome de uma heroína de novela mostra ainda mais o desejo de ser ficção, de emocionar, marca presente em textos memorialísticos elaborados com intuito de construir a identidade do escritor. 
Dessa forma, fortalece-se a ideia de "escritor herói", escolhido e encaminhado para essa função por todas as circunstâncias que o rodeavam:

Uma autoficção é uma obra literária através da qual um escritor inventa para si uma personalidade e uma existência, embora conservando sua identidade real (seu nome verdadeiro). Embora intuitiva, essa definição possibilita desenhar os contornos de uma extensa classe, de um rico conjunto de textos: uma região literária parece dessa forma emergir do limbo da literatura (LEJEUNE,2014, p. 26).

O escritor continua sendo o herói de sua história, o pivô em torno do qual a matéria narrativa se ordena, mas fabula sua existência a partir de dados reais, permanece mais próximo da verossimilhança e atribui a seu texto uma verdade ao menos subjetiva ou até mais que isso (COLONNA, 2014, p. 44).

As mulheres que rodeiam a narradora, por sua vez, são tristes, misteriosas, marcadas pela morte e pela luta por voz. A avó materna é descrita como quem "andava pelo mundo em passinhos de feltro, pedindo desculpas por existir" (BRUM, 2017, p. 31). Todavia, é quem lhe conta os causos de Pedro Malasartes e inventava maravilhas de restos de tecidos, como os vestidos das bonecas e capas de chuva para os netos:

Mas o melhor da minha vó eram as histórias urdidas com retalhos pinçados do território sem fronteiras do ontem. Ela era cheia de contos, e eu tinha ouvidos gulosos. Desde pequena, sou capaz de permanecer horas só escutando, sem a necessidade de falar de mim mesma. Pelas fábulas de familia minha avó resgatava um pretérito que nunca teve. Se não era possivel alcançar um amanhecer mais próximo de seus suspiros, ela compensava alinhavando seu antes com linhas bem coloridas, ás vezes, extravagantes. Minha avó sabia que, para algumas vidas, é mais fácil mudar o passado que o futuro (BRUM, 2017, p. 32).

Doubrovsky (2014), ao refletir sobre a autoficção, afirma que ela é uma espécie de modelagem ou roteirização romanesca da própria vida. Logo, o fato de a avó da narradora transmitir o poder não apenas das histórias, mas também da alteração da própria história, nos mostra mais uma vez uma possibilidade de teorização da memória dentro do livro. Além disso, o casamento infeliz da avó devido a um engano também ocorrido por meio das palavras (as cartas de amor recebidas eram escritas pela irmã do avô, não por ele), faz com que surja um alerta - tendencioso - dentro da narrativa: não há reparação para a palavra escrita e "Essa foi uma lição definitiva para a neta que um dia se tornaria repórter e contaria história de gente" (BRUM, 2017, p. 39).

Outra figura importante na formação da identidade é a tia Ivone. Por meio dela, é construida a metáfora de um jardim que nos falará também da sexualidade e da maturidade da narradora: "Não era um jardim, era uma floresta. Darwin poderia ter construído pelo menos uma parte de sua teoria sem sair do jardim da minha tia." (BRUM, 2017, p. 45). A ideia de ver as estações passarem e entregar-se ao "caos da vegetação indomável" do jardim diz sobre a transformação de uma menina em mulher e a descoberta de sua sexualidade, como o desabrochar de uma das flores, e retoma ainda mais a presença da metáfora do corpo como mistério, terra que brota e dá vida:

As mulheres da minha familia gestavam jardins
furiosos. Havia algo de inquietante naque-
la selva para a qual me carregavam, e onde
eu me sentia mais viva do que em qualquer
outro lugar da infância. Ainda sem perceber
que era lá que o coração daquelas mulheres
pulsava em desatino, para onde escapavam
de um corpo em que o desejo fora sepultado
sob a lápide do casamento, das convenções
e dos dias. Era lá que seu sexo pulsava, úmi-
do e quente, devorando e sendo devorado,
enquanto elas ajeitavam os bobes no cabelo
(BRUM, 2017, p. 43).

Sobre seu progenitor, a narradora conta que, após ele adoecer com doze anos, ao acordar descobre ter perdido o pai (avô de Eliane). Ali entende que "ler pode ser uma maldição" (BRUM, 2017, p. 65), preço que ainda assim decide pagar. Doravante, decide preencher a ausência com palavras e aprender a ler, porém não é a ele que a narradora atribui papel no seu elenco, mas sim à professora que o alfabetiza: Luzia.

Luzia fora a responsável por "tirar a cegueira" do pai, apresentá-lo aos livros e, consequentemente, influenciar o destino da narradora, pois, segundo ela "Com a memória de Luzia, fiz meu parto para a vida - e a vida era a palavra escrita" (BRUM, 2017, p. 68). Graças a ela, o pai adulto também apresenta os livros à filha (Eliane), que se torna leitora voraz (dos 
livros infantis até os adultos disponíveis na casa).

Outra personagem importante para sua identidade literária é a atendente de livraria Lili, que a deixava ler diversas obras sem que precisasse pagar por elas. Por isso, Eliane diz ter passado muito tempo na loja explorando as possibilidades de títulos, liberdade que acaba quando Lili deixa o local e elas perdem o contato. A narradora conta inclusive que, já adulta, pode reencontrar a atendente por meio de um texto de jornal, e que é "uma repórter de desacontecimentos desde que Lili "desaconteceu" da sua vida" (BRUM, 2017, p. 92).

Prosseguindo sobre os motivos de escrita da escritora, temos seus conflitos com um grupo de crianças que viviam na rua, do qual a única menina do bando, especificamente, chama sua atenção. Essas crianças a ameaçam com seringas e lhe roubam 7 cruzeiros, porém, não satisfeitas, seguem provocando-a nos arredores da escola. Tempos depois, quando a narradora tem quinze anos, revê a menina do bando se prostituindo na rua. Sobre isso, diz:

Escrevo também para mantê-la viva. Ela me ensinou que os dentes do mundo estão sobre nossos corpos. Muito mais no corpo dela do que no meu. Não há nada pior - nada - do que ser criança, menina, e viver (e morrer) no desamparo. Em algum momento no qual nossos olhos se encontraram, eu compreendi que a guerra não era entre nós. Nunca havia sido entre nós. Em algum momento, fiz minha escolha. Por ela, por mim. Essa escolha definiu o que sou. (BRUM, 2017, p. 103)

Atribuir sua escolha de escrever como forma de manter a menina de sua memória viva reforça a tese de que a escrita é o destino para o qual todos os acontecimentos convergem. Por meio dela, até mesmo a diferença social permite que o lugar da narradora seja um caminho até a possibilidade da voz de denúncia. A figura do índio que escrevia AveMarias, no capítulo seguinte, contribui igualmente para o ideal de escrever em prol do injustiçado, o deslocado, aquele que vive a margem.

Por fim, temos a lembrança de quando o pai publica um livro da narradora, escrito aos nove anos. Sob o título de Gotas da infância (ideia dele), a obra é lançada em um salão lotado, porém, ao término, a filha se sente nua: "Senti como se cada um que tivesse levado o livro para casa possuísse agora um pedaço de mim" (BRUM, 2017, p. 114), diz ela. A ideia da "escrita-corpo", que entrega suas partes ao leitor enquanto é lida, despe e expõe os segredos da menina, tornando a experiência algo traumático. Em um primeiro momento, a memória final parece deslocada da cronologia das demais, todavia é certeira para a conclusão intencional da autora: fora esse fato que a fizera parar de escrever e entrar na adolescência sem palavras. Muito embora esse fato possa causar estranhamento, visto que Eliane conta ter tido uma filha com quinze anos, mas omite do leitor a história da gravidez, podemos justificar tal "esquecimento" ao protagonismo intencional da palavra, logo que, se havia apenas o silêncio (marcado inclusive por uma página apenas com essa palavra), não há o que se contar sobre uma vida com as palavras (referência ao subtítulo da obra), justamente por não ser parte do objetivo estabelecido desde o início e demonstrar, nas poucas referências existentes, um periodo conturbado de sua vida. As pistas dadas ao leitor sobre o periodo, dadas apenas em duas páginas, afirmam o sofrimento diante da decepção do pai, a vergonha e o silêncio:

\begin{abstract}
Entre o lançamento do meu primeiro livro, aos onze anos, e a bomba do Leonam, aos vinte e um, eu vi meu corpo de menina virar corpo de mãe. Eu era um corpo que se transformava ao ser violado de fora para dentro e de dentro para fora. Tão incorporada estava que me desincorporei. Tomada pela literalidade da carne, a abissal realidade do corpo, me perdi da possibilidade de me subjetivar pelas palavras. Eu era delicada demais para a puberdade e para toda a violência que vem com a condição feminina quando o corpo se torna um corpo para o sexo. [...] Quando engravidei, aos quinze anos, eu não conseguia dizer. Tentava contar aos meus pais, mas a voz não saia. [...] As palavras calaram-se em mim. Restava-me um corpo de menina transformando-se em corpo de mãe, sem ter virado corpo de mulher. A metamorfose de Kakfa não alcançava o que senti. Naquele momento perdi também a palavra oral (BRUM, 2017, p. 122-123).
\end{abstract}

Com isso, a obra pula da adolescência para a vida adulta e nos mostra uma mulher diante do retorno aos próprios fantasmas, começando pela 
irmã morta. É necessário escrever para superar o luto, para livrar-se da morte, para dar grafia àquela que lhe deu uma bio. O "eucaos" inicial se justifica e reitera a explosão do gênesis: o verbo chama à existência (ou (re)existência) a própria narradora. O último capítulo, "salva por uma bomba", fala da ressignificação e renascimento da narradora, que, já na faculdade, escuta palavras de um professore consegue, por fim, o big bang de seu despertar ao afirmar que "libertei as letras, e elas emergiram dos meus abismos como voragem. Voltei a escrever. Dessa vez, uma vida para mim" (BRUM, 2017, p. 125).

Conforme Carlos e Esteves (2009, p. 17). "ao se falar de veracidade na escrita autobiográfica, aponta-se não para a verdade, em si mesma inapreensivel, mas para aquela estabelecida pelos limites do pacto biográfico". Logo, ao entrarmos no pacto proposto em Meus Desacontecimentos, somos levados a testemunhar o protagonismo da palavra na infância da narradora e seu destino que, de antemão, já nos mostrava o jornalismo dos desacontecimentos e seus diálogos com a literatura. Muitas ainda são as discussões sobre o gênero autobiográfico, a teorização da memória em obras e a idealização da infância, para as quais a presente obra se preza a análise ainda mais detalhada. Todavia, prefiro situá-la no campo literário ao evocar os versos de Mário Quintana sobre o poder da palavra.

\section{Emergência \\ Quem faz um poema abre uma janela \\ Respira, tu que estás numa cela abafada, esse ar que entra por ela. \\ Por isso é que os poemas têm ritmo \\ - para que possas profundamente respirar. \\ Quem faz um poema salva um afogado. \\ (QUINTANA, 20015)}

Sim, sobre isso não restam dúvidas: a palavra - versada, cantada, narrada ou (por que não?) memorada em ficção - pode salvar um afogado. Ela é possibilidade, é reinvenção e refúgio. É quem nos permite voltar no tempo e apaziguar nossos fantasmas, formando versões que reconstituam e liguem as pontes entre passado e presente. Para Eliane Brum, revisitar o percurso que a levou até as letras - por mais ficcionado que possa ou não parecer - é recordar a abertura de suas celas e expor de novo o corpo nu, que agora doa, voluntariamente, seus pedaços ao leitor.

\begin{abstract}
A palavra é o outro corpo que habito. Não sei se existe vida após a morte. Desconfio que não. Sei que para mim não existe vida fora da palavra escrita. Só sei ser - por escrito. No meu nome carrego o que sou e o que não sou, sustento o que busco e não alcanço, assim como o vazio entre as letras, o incapturável de mim. O indizivel que também me constitui (BRUM, 2017, p. 73).
\end{abstract}

\section{Referências}

ASSMANN, Aleida. Espaços da recordação. Formas e transformações da memória cultural. Campinas: Editora da UNICAMP, 2011. p. 15-158.

BRUM, Eliane. Meus desacontecimentos: a história da minha vida com as palavras. São Paulo: Leya, 2014.

BRUM, Eliane. Desacontecimentos. Disponivel em: http://elianebrum.com/biografia/ Acesso em: 28 maio 2019

CARLOS, Ana Maria; ESTEVES, Antônio R. Narrativas do eu: memórias através da escrita- Ensaios. Bauru: São Paulo, 2009

COLONNA, Vincent. Tipologia da Autoficção. In: NORONHA, Jovita Maria Gerheim (org.). Ensaios sobre a autoficção. Belo Horizonte: Editora UFMG, 2014. p. 39-66.

DOUBROVSKY, Serge. O último eu. In: NORONHA, Jovita Maria Gerheim (org.). Ensaios sobre a autoficção. Belo Horizonte: Editora UFMG, 2014. p. 111-126.

HALL, Stuart. A Identidade Cultural na Pós-Modernidade. TradUÇÃO: Tomaz Tadeu da Silva e Guacira Lopes Louro. 10. ed. Rio de Janeiro: DP\&A, 2005.

LEJEUNNE, Phelipe. Autoficções \& cia: peça em cinco atos. In: NORONHA, Jovita Maria Gerheim (Org.). Ensaios sobre a autoficção. Belo Horizonte: Editora UFMG, 2014. p. 21-37.

MARIANO, Agnes Franciane de Carvalho. Eliane Brum e a arte da escuta. Em Questão, Porto Alegre, v. 17, n. 1, p. 307-322, jan./jun. 2011.

QUINTANA, Mário. Emergência. In: MORICONI, Ítalo (org.). Os cem melhores poemas brasileiros do século. Rio de Janeiro: Objetiva, 2001. p. 117.

RESTREPO, Laura. El extrãno enano. El País, Babélia, p. 1-2, 3 mar. 2008. 
RICOEUR, Paul. A memória, a história e o esquecimento. Campinas: Editora da UNICAMP, 2007. p. 25-70.

SOUSA, Roberto Acizelo de. Teoria da literatura. São Paulo: Ática, 2007.

STRICHTER, Luzimar. Eliane Brum no divã: meus desacontecimentos. 2018. 1 vídeo (42 min 18 s). Publicado pelo Canal Luzimar Stricher. Palestra realizada na $63^{\mathrm{a}}$ Feira do Livro de Porto Alegre em 14 de novembro de 2014. Disponivel em: https://www.youtube. $\mathrm{com} /$ watch? $\mathrm{v}=\mathrm{Sgm} 38 \mathrm{Aj} 3 \mathrm{MsU} \& \mathrm{t}=2156 \mathrm{~s}$ Acesso em: 28 maio 2019.

VENTURA, Mario Souza de; ABIB, Tayane Aidar. O desacontecimento em narrativas esportivas: análise das produções jornalisticas de Eliane Brum sobre a Copa do Mundo de 2014. Estudos em Jornalismo e Midia, Florianópolis, v. 13, n. 1, p. 56-67, 2016. https:// doi.org/10.5007/1984-6924.2016v13n1p56

VILAIN, Philippe. A prova do referencial. In: NORONHA, Jovita Maria Gerheim (org.). Ensaios sobre a autoficção. Belo Horizonte: Editora UFMG, 2014. p. 163-179.

\section{Endereço para correspondência}

Karine Conte de Mattos da Costa

Av. Ipiranga, 6681, Escola de Humanidades

Partenon 90619-900

Porto Alegre, RS, Brasil

\section{Karine Conte de Mattos da Costa}

Mestranda em Teoria da Literatura no Programa de Pós-Graduação em Letras da Pontifícia Universidade Católica do Rio Grande do Sul (PUCRS), bolsista CAPES. 